\title{
As ações possessórias como instrumento de garantia da ordem social
}

Entender a relação do indivíduo com o direito à posse acarreta em diversas consequências, sendo uma delas a forma como a busca pelo possuir pode provocar grandes embates sociais, fazendo com que alguns instrumentos, dentre eles as ações possessórias, sejam criados com objetivo de assegurar soluções para estes litígios possessórios. Logo, o objetivo principal deste artigo é compreender de que forma as ações possessórias, em especial a de reintegração e manutenção de posse, podem ser vistas como mecanismos de garantia da ordem social. Além disso, têm-se os objetivos de discutir a natureza jurídica da posse e sua relação com o homem natural, além da interligação entre a prática de atos de esbulho e turbação com a não efetividade do direito social à moradia, para que assim se possa entender como as ações possessórias previstas no Código de Processo Civil caracterizariam uma maneira de garantir a ordem social. Para tal, foi utilizado o método dedutivo, de modo que a pesquisa apresenta natureza qualitativa, estando alicerçada por um levantamento bibliográfico documental e eletrônico, juntamente com o uso de fontes cinematográficas e jornalísticas. Em conclusão, o presente estudo agrega contribuições tanto para o âmbito acadêmico quanto para o mundo jurídico como um todo, uma vez que permite o exame sobre um dos direitos mais debatidos ao longo da história, fazendo com que a tutela jurídica ofertada pelo Poder Judiciário seja ainda mais eficiente e o Direito cumpra o seu papel de resguardar a paz social.

Palavras-chave: Posse; Direito social à moradia; Ações possessórias; Ordem social.

\section{The possessory actions as an instrument of guarantee of the social order}

\begin{abstract}
Understanding the relationship of the individual with the right to possession entails several consequences, one of which is how the search for possession can cause major social clashes, causing some instruments, among them possessive actions, to be created in order to ensure solutions for these possessive disputes. Thus, the main objective of the article is to understand how the possessive actions, especially the reintegration and maintenance of possession, can be seen as mechanisms of social order guarantee. In addition, the objectives are to discuss the legal nature of possession and its relationship with the natural man, as well as the interconnection between the practice of busting and turmoil with the ineffectiveness of the social right to housing, so that can understand how the possessive actions provided for in the Code of Civil Procedure would characterize a way of guaranteeing social order. For this, the deductive method was used, so the research presents a qualitative nature, being based on a documental and electronic bibliographic survey, along with the use of cinematographic and journalistic sources. In conclusion, the present study adds contributions to both the academic and the legal world as a whole, as it allows the examination of one of the most debated rights in history, making the legal protection offered by the Judiciary Power even more efficient and the law fulfills its role of safeguarding social peace.
\end{abstract}

Keywords: Possession; Social right to housing; Possessory actions; Social order.

Topic: Direito Civil e Processo Civil

Reviewed anonymously in the process of blind peer.
Received: 10/07/2019

Approved: 22/10/2019

Kamilee Lima de Oliveira (iD

Faculdade de Administração e Negócios de Sergipe, Brasil

http://lattes.cnpq.br/6354991127871034

http://orcid.org/0000-0002-2034-7074

kamileelima2@hotmail.com

\section{Referencing this:}

LIMA, K.. As ações possessórias como instrumento de garantia da ordem social. Justitia Liber, v.1, n.2, p.1-16, 2019. DOI: http://doi.org/10.6008/CBPC2674-6387.2019.002.0001 


\section{INTRODUÇÃO}

A sociedade brasileira sempre foi marcada por inúmeras desigualdades, com destaque para a desigualdade social, onde temos, de um lado, grupos detentores de todo o poder e, de outro, classes que não são alcançadas sequer pelo básico. Exemplo que ilustra tamanha discrepância está no fato de, ainda, existirem inúmeras pessoas que não possuem residência própria, de maneira que são obrigadas a recorrerem ao aluguel de imóveis ou até mesmo a viverem nas ruas.

Além disto, a falta de alcance no cumprimento de um dos direitos sociais entabulados na nossa Magna Carta, o direito à moradia, faz com que, por muitas vezes, determinado possuidor seja privado de exercer sua posse por alguém que acaba usurpando ou embaraçando a plena posse daquele que detém o direito de propriedade e, consequentemente, o de exercício da posse. Por meio disso, vários conflitos sociais são causados, de modo que cada um dos conflitantes defenderá os seus interesses individuais, resultando em uma perturbação da paz social.

Diante de tamanha magnitude e relevância temática é que resta esclarecida a importância do estudo da posse como um dos institutos mais significativos do ordenamento jurídico, passando a ser, inclusive, tutelado por intermédio das chamadas ações possessórias, com previsão expressa no Código Processual Civil. Portanto, está nítida a relação intrínseca do direito à moradia e do direito à posse com a ordem social.

Surgindo da curiosidade de entender o porquê da criação das ações possessórias expressas no Código de Processo Civil, o que se pretende com este estudo é a compreensão do verdadeiro objetivo pelo qual o Estado, através de suas ferramentas processuais, se predispôs a proteger a posse. Esta não é uma inquietude recente, longe disso. $\mathrm{O}$ debate acerca da natureza jurídica da posse e das razões pelas quais foram criadas as ações possessórias ocorre desde os primórdios romanos, perpetuando-se até os presentes dias.

Destarte, se faz notória a importância deste objeto de estudo, tanto para a comunidade acadêmica quanto para a sociedade como um todo. Para o mundo acadêmico, tal discussão ainda alastra as universidades jurídicas espalhadas pelo mundo, sempre sendo colocadas em questão as posições dos famosos juristas Savigny e Ihering, ambos com defensores e opositores mundiais.

Já para a sociedade, talvez a maior beneficiada com este trabalho, o exame dos motivos ensejadores das ações possessórias pode garantir uma maior efetividade para os processos que estão em curso e para aqueles que estão por vir, uma vez que o conhecimento do real significado da tutela possessória permitirá um maior desempenho por parte dos magistrados no deslinde dos casos que tenham a posse como fator principal. Diante do que foi colocado, o presente estudo buscará responder o seguinte questionamento: como as ações possessórias constituem um instrumento de garantia da ordem social?.

O caminho para encontrar a resposta desta indagação será construindo por meio de objetivos, tendo como principal analisar de que forma as ações possessórias previstas no Código de Processo Civil constituem um instrumento de garantia da ordem social. Já os objetivos específicos estarão contidos em cada capítulo integrante deste trabalho. Primeiro, restaram explicitadas as principais teorias sobre a natureza jurídica da posse, bem como uma demonstração de como era a relação do homem natural com a posse. Após, serão 
conceituados os atos violentos de esbulho e turbação, havendo uma sucinta exposição da história do direito social à moradia, sendo feita uma relação entre a não efetividade do direito social à moradia e a prática de esbulho e turbação. Por último, colocar-se-á os motivos causadores da criação da tutela da posse, revelando a importância das ações possessórias na manutenção ou no reestabelecimento da ordem social.

\section{METODOLOGIA}

Aspirando o melhor desenvolvimento do artigo, o método científico adotado é o dedutivo, onde se parte de premissas gerais para premissas particulares, para que os objetivos postos sejam alcançados. Com isso, a pesquisa é dotada de natureza qualitativa, uma vez que serão analisadas características e qualidades dos diversos institutos pesquisados, como a posse e sua natureza jurídica, as ações possessórias previstas no ordenamento processual brasileiro, o direito à moradia, dentre outros, tendo como alicerce um levantamento bibliográfico, tanto documental como eletrônico, formado por livros físicos, e-books, artigos científicos, legislação, jurisprudências, filmes e notícias jornalísticas.

\section{DISCUSSÃO TEÓRICA}

\section{Teorias Sobre a Natureza Jurídica da Posse}

Antes de adentrarmos diretamente no estudo objeto da presente monografia, é preciso definir o instituto da posse, bem como identificar sua natureza jurídica, conforme se passa a expor. Registre-se que a definição de posse perpassa por duas correntes que tratam da natureza jurídica do referido instituto, a teoria subjetivista de Friedrich Carl von Savigny e a teoria objetivista de Rudolf von Ihering. Tartuce define a teoria de Savigny dizendo que

Seu principal idealizador foi Friedrich Carl von Savigny, entendendo a posse como o poder direto que a pessoa tem de dispor fisicamente de um bem com a intenção de detê-lo para si e de defendê-lo de contra a intervenção ou agressão de quem quer que seja. (TARTUCE, 2017)

Assim, podemos identificar dois elementos presentes na posse subjetivista de Savigny, o corpus e o animus. O corpus nada mais é que o corpo físico a ser possuído, já o animus é a vontade de ter para si o corpus (VENOSA, 2003). Como grande opositor da teoria acima explicitada, temos Ihering com a teoria objetivista da posse que, e segundo Tartuce, "[...] para a conceituação da posse basta que a pessoa disponha fisicamente da coisa, ou que tenha a mera possibilidade de exercer esse contato" (TARTUCE, 2017). Ou seja, o elemento animus é dispensável, de modo que para que possamos definir alguém como possuidor não será preciso que esse alguém tenha a intenção de possuir o corpus.

Cabe, ainda, pontuar que Diniz (2002) traz uma terceira corrente sobre a natureza da posse, a que defende que a posse é um fato, tendo como um dos seguidores Bernhard Windscheid. A autora, ao tratar da posse como direito real, aduz:

[...] posto que é a visibilidade ou desmembramento da propriedade. Pode-se aplicar o princípio de que o acessório segue o principal, sendo a propriedade o principal e a posse, o acessório, já que não há propriedade sem posse. Nada mais objetivo do que integrar a posse 
na mesma categoria jurídica da propriedade, dando a possuidor tutela jurídica. (DINIZ, 2002)

Tartuce (2017) também foge do tradicionalismo civilista e assume a posição de que

[...] a posse é um direito de natureza especial, o que pode ser retirado da teoria tridimensional do Direito, de Miguel Reale. Isso porque a posse é o domínio fático que a pessoa exerce sobre a coisa. Ora, se o Direito é fato, valor e norma, logicamente a posse é um componente jurídico, ou seja, um direito. (TARTUCE, 2017)

Também, necessário mencionar que dentre os civilistas, há a escolha de um dos lados antagônicos entre Savigny e Ihering, como Venosa (2003) que optou por seguir o pensamento segundo o qual a posse tem natureza objetiva, valendo-se do seguinte argumento:

Seguindo a tradição romana e dentro da teoria exposta por Jhering, adotada como regra geral em nosso Direito, enfoca-se a posse como um postulado da proteção da propriedade. Trata-se de complemento necessário do direito de propriedade. A proteção possessória, pelas vias processuais adequadas dentro do ordenamento, surge então como complemento indispensável ao direito de propriedade. (VENOSA, 2003)

Por meio do supracitado fragmento, Venosa (2003) informa que o ordenamento jurídico pátrio adotou a teoria objetivista de Ihering, o que resta demonstrado no artigo 1196 do Código Civil, "Considerase possuidor todo aquele que tem de fato o exercício, pleno ou não, de algum dos direitos inerentes à propriedade" (BRASIL, 2002). Sendo assim, o legislador brasileiro entendeu que possuidor é aquele que exerce domínio sobre a coisa, estando descartada a intenção subjetiva de ter a dita coisa para si.

Todavia, Tartuce (2017) acredita que a teoria objetivista de Ihering não foi absolutamente absorvida pelo dispositivo acima transcrito. Para ele, o artigo. 1196 do Códex abrange a teoria de Ihering de forma parcial (TARTUCE, 2017), concluindo que “[...] é mais correto afirmar que o Código Civil de 2002 não adota a tese de Ihering pura e simplesmente, mas sim a tese da posse-social, sustentada por Perozzi, Saleilles e Hernandez Gil" (TARTUCE, 2017). A posse-social é o fundamento das chamadas teorias sociológicas da posse, que tem como pensadores os juristas sociólogos acima citados. De acordo com Gonçalves (2017),

Essas novas teorias, que dão ênfase ao caráter econômico e à função social da posse, aliadas à nova concepção do direito de propriedade, que também deve exercer uma função social, como prescreve a Constituição da República, constituem instrumento jurídico de fortalecimento da posse, permitindo que, em alguns casos e diante de certas circunstâncias, venha a preponderar sobre o direito de propriedade.

Assim, as teorias sociológicas se baseiam na função social da propriedade, que, em última análise é a moradia, habitação, prevista no art. 50, XXIII, da Constituição Federal (BRASIL, 1988), para fazer com que a posse também busque a concretização dessa função. Tratadas as principais correntes doutrinárias acerca da natureza jurídica da posse, importante salientar que por longo período de tempo, verificou-se a discussão da posse em torno das teorias de Savigny e de Ihering. Com o passar dos anos, os juristas, ampliaram as teorias sobre a posse, afastando-se dos jurisconsultos alemães, criando novas vertentes para explicar o que é a posse.

Atualmente, é forçoso concluir que não há mais divergência legal sobre qual das teorias fora adotada pelo ordenamento jurídico brasileiro, estando consolidado o entendimento de que se adota a teoria objetivista de Ihering sobre a posse. Superados o conceito e a natureza jurídica da posse, passa-se a discorrer sobre breve histórico do instituto correlacionando a posse com o homem no decorrer dos tempos. 


\section{A Relação do Homem Natural com a Posse}

Antes de se tratar diretamente do estudo das ações possessórias, faz-se necessário entender como se deu a relação do homem natural com a posse. Para tal, utiliza-se as ideias dos chamados filósofos jusnaturalistas, dentre eles Thomas Hobbes, John Locke e Jean-Jacques Rosseau. Para Hobbes (2003), os homens em seu estado natural, desprovidos de qualquer poder coercitivo, viviam em condição de tamanha igualdade que dispunham dos mesmos meios para alcançar o que desejavam, de modo que havia uma acirrada disputa. Com isso, se determinado indivíduo almejasse o mesmo que outro, estes homens, inevitavelmente, virariam inimigos. Assim, Hobbes (2003), em sua obra de maior renome, o Leviatã, entende o homem e a posse da seguinte maneira:

[...] quando um invasor nada mais tem a recear do que o poder de um único outro homem, se alguém planta, semeia, constrói ou possui um lugar cômodo, espera-se que provavelmente outros venham preparados com forças conjugadas, para o desapossar e privar, não apenas do fruto do seu trabalho, mas também da sua vida ou da sua liberdade. Por sua vez, o invasor ficará no mesmo perigo em relação aos outros.

Dessa forma, resta claro que o homem natural hobbesiano vivia sob constante temor de perder sua posse, já que não tinha qualquer garantia estatal, de modo que apenas a possuía enquanto não fosse usurpado pelo seu semelhante. Em contraposição, Locke (1978), em seu Segundo Tratado Sobre o Governo, enxerga a posse dos homens por um viés mais religioso.

De acordo com Locke (1978), Deus concedeu a humanidade uma terra comum, sendo que "o trabalho tinha de servir-lhe ao direito de posse". Portanto, apesar de gozarem de algo em comum, o homem só teria direito de posse sobre aquilo no qual dispusesse sua força de trabalho, como bem colocado pelo filósofo, "A extensão da terra que um homem lavra, planta, melhora, cultiva, cujo produtos usa, constitui sua propriedade. Pelo trabalho, por assim dizer, separa-a do comum" (LOCKE, 1978).

Ainda, é importante destacar que, conforme o pensamento lockeano, para que o indivíduo se tornasse possuidor de uma porção de terra, não era necessário o consentimento dos demais homens conviventes daquela sociedade, pois o próprio trabalho empregado conferiria a este homem o título de possuidor do montante de terra, com isso:

A tomada desta ou daquela parte não depende do consentimento expresso de todos os membros da comunidade. Assim a grama que meu cavalo pastou, a turfa que que o criado cortou, o minério que extraí em qualquer lugar onde a ele tenho direito em comum com outros, tornam-se minha propriedade sem a adjudicação ou o consentimento de qualquer outra pessoa. O trabalho que era meu, retirando-os do estado comum em que se encontravam, fixou a minha propriedade sobre eles. (LOCKE, 1978)

Por último, observa-se como Jean-Jacques Rosseau lidou com a posse do homem em estado de natureza. Em O Contrato Social, o contratualista coloca que ao ser firmado o pacto social o homem abre a mão de sua liberdade natural, absolutamente ilimitada, por uma liberdade civil, na qual o Estado é o instrumento limitador. Por consequência, em estado de natureza há a posse, enquanto que em estado civil o que existe é a propriedade, de forma que, para Rosseau, a posse é um mero direito de primeiro ocupante, já a propriedade é um direito consubstanciado em um título positivado (ROSSEAU, 2006). O filósofo suíço 
postula alguns requisitos para que o homem seja possuidor de determinada terra enquanto ainda não houver firmamento do contrato social, conforme se segue:

Em geral, para autorizar o direito do primeiro ocupante sobre um terreno qualquer, são necessárias as seguintes condições: primeiro, que esse terreno não esteja ainda habitado por ninguém; segundo, que dele só se ocupe a porção de que se tem necessidade para subsistir; terceiro, que dele se tome posse, não por uma cerimônia vã, mas pelo trabalho e o cultivo, únicos sinais de propriedade que, na ausência de títulos jurídicos, devem ser respeitados pelos outros. (ROSSEAU, 2006)

Destarte, assim como Locke (1978), Rosseau (2006) pensou a posse como algo conquistado pelo esforço do possuidor, assim, enquanto o homem estiver cuidando do seu pedaço de terra, ele terá direito de posse sobre ele, afastando com isso, a possibilidade de usurpação legítima por parte dos outros cidadãos. Apesar de dizer ser indispensável o respeito ao direito do primeiro ocupante, Rosseau também afirma que tal direito "[...] embora mais real que o do mais forte, só se torna um verdadeiro direito após o estabelecimento do direito de propriedade" (ROSSEAU, 2006). Posto isto, podemos dizer que o referido pensador não desenhou o direito de posse em estado natural, uma vez que, como dito, apenas tornar-se-ia um direito quando fosse estabelecido o estado civil. A seguir, será abordado o direito social à moradia e a sua conexão com a prática de atos violentos, como o esbulho e a turbação.

\section{Do Esbulho e da Turbação}

O artigo 1200 do Código Civil Brasileiro traz que "é justa a posse que não for violenta, clandestina ou precária" (BRASIL, 2002). Por conseguinte, em oposição, tem-se que é injusta a posse que for conquistada de maneira violenta, clandestina ou precária. Mas como pode se identificar cada um dos referidos vícios?. Pois bem, Tartuce (2017) coloca em seu Manual de Direito Civil as seguintes definições e exemplificações para posse violenta, clandestina e precária, respectivamente:

Posse violenta - é a obtida por meio de esbulho, for força física ou violência moral (vis). A doutrina tem o costume de associá-la ao crime de roubo. Exemplo: movimento popular invade violentamente, removendo e destruindo obstáculos, uma propriedade rural produtiva, que está sendo utilizada pelo proprietário, cumprindo a sua função social.

Posse clandestina - é a obtida às escondidas, de forma oculta, à surdina, na calada da noite (clam). É assemelhada ao crime de furto. Exemplo: movimento popular invade, à noite e sem violência, uma propriedade rural que está sendo utilizada pelo proprietário, cumprindo a sua função social.

Posse precária - é a obtida com abuso de confiança ou de direito (precário). Tem forma assemelhada ao crime de estelionato ou à apropriação indébita, sendo também denominada esbulho pacífico. Exemplo: locatário de um bem móvel que não devolve o veículo ao final do contrato.

Posto isto, é patente que os institutos ora analisados, a saber, o esbulho e a turbação, integram o conceito da posse tida como violenta. Os citados fenômenos jurídicos são amplamente conhecidos por todos, até mesmo pela população mais desprovida de conhecimento técnico, afinal, exemplos diários de violência sobre a posse podem ser vistos nos noticiários nacionais, de forma que qualquer cidadão é capaz de identificar quando outrem invade de forma violenta o imóvel de outrem ou perturbar-lhe a posse. Todavia, mesmo o esbulho e a turbação sendo vistos como fatos sociais é crucial que haja uma apresentação, ainda que sucinta, das principais definições destes dois atos violentos. 
Deste modo, far-se-á uso de renomados processualistas civis brasileiros. O primeiro deles é Alexandre Freitas Câmara, Desembargador do Tribunal de Justiça do Rio de Janeiro, autor do livro Lições de Direito Processual Civil, que acredita que "[...] ocorre esbulho quando há perda total da posse, molestada injustamente por outrem" (CÂMARA, 2010). Assim, o esbulhador priva o possuidor por completo do exercício da sua posse, de maneira tal que há uma inversão na titularidade da posse, isto é, o responsável pelo esbulho torna-se possuidor, embora injustamente.

Complementando, para elucidar o que seria a turbação, Câmara (2010) diz que "Difere a turbação do esbulho, pois, pelo fato de que neste ocorre a perda total da posse, enquanto naquela a posse se mantém, com limitações impostas pela turbação". Desta forma, a turbação pode ser vista como uma verdadeira perturbação ao direito possessório, sem que a posse se transfira. Para não restar dúvidas quanto à distinção entre os dois fenômenos, o jurista oferece o subsequente exemplo:

\begin{abstract}
Exemplifique-se, para demonstrar a distinção: se alguém invade uma área destinada a pastagem de gado, retira dálias reses do proprietário de terra e, impedindo, a utilização da área pelo dono, ali põe seu gado a pastar, ter-se-á esbulho. De outro lado, se alguém invade a área destinada a pastagem de gado e ali, sem retirar as reses do proprietário, põe seu gado para pastar junto com o do legítimo possuidor, tem-se turbação. (CÂMARA, 2010)
\end{abstract}

Passando para o pensamento de outro notório processualista, chega-se a figura de Humberto Theodoro Júnior, que, no que tange à violência contra posse, segue o mesmo entendimento de Câmara, uma vez que também visualiza o esbulho como a perda total da posse, porém, Theodoro fornece informações complementares ao indicar que

Essa perda total da posse pode decorrer:

(a) de violência sobre a coisa, de modo a tirá-la do poder de quem a possuía até então;

(b) do constrangimento suportado pelo possuidor, diante do fundado temor de violência iminente;

(c) de ato clandestino ou de abuso de confiança. (THEODORO JÚNIOR, 2016).

Com isso, notam-se as formas com as quais o esbulho pode se revestir, o verdadeiro modus operandi do esbulhador, que conseguirá privar alguém da posse seja pela violência física, psicológica ou por um abuso de confiança. Theodoro Júnior (2016) não se estende muito sobre a turbação, apenas colocando que o objetivo da ação de manutenção da posse "[...] é fazer cessar o ato do turbador, que molesta o exercício da posse, sem contundo eliminar a própria posse", corroborando, mais uma vez, com o pensamento de Câmara.

Por fim, o doutrinador Wilson Gianulo (2008), em obra batizada de Procedimento Especiais: doutrina, prática forense e legislação, disserta que a turbação "[...] se opera sem que se dê a exclusão completa da posse pelo esbulhador em detrimento ao possuidor, identificando-se, pois, com perda parcial da posse [...]". Percebe-se, desse modo, que o autor segue o pensamento da maioria dos juristas no que diz respeito à turbação, entendendo-a como um ato que importa em perda parcial da posse sobre o objeto.

Quanto ao esbulho, Gianulo (2008) exprime suas intenções nesta passagem:

O esbulho, por conseguinte, está plenamente identificado com a subtração da totalidade da coisa possuída e não parte dela, residindo na abrangência a diferença entre a turbação e o esbulho, porque este abrange a totalidade do objeto ao passo que aquele apenas parte da totalidade. 
Através deste fragmento, é possível notar que Gianulo diferencia esbulho de turbação por meio do objeto a ser violentado, de maneira, que todo o objeto for usurpado haverá a prática de esbulho; se, conquanto, apenas parte do objeto for tomado estar-se-ia diante de turbação. Compreendida o que é a posse justa, bem como as formas pelas quais a posse se torna injusta, em destaque para os atos de esbulho e turbação, passa-se a uma viagem ao passado em busca da evolução do direito social à moradia.

\section{Do Direito Social à Moradia: Um Retrospecto Histórico}

O atualmente conhecido direito à moradia nem sempre esteve positivado nas diversas Constituições Brasileiras, tampouco como um direito fundamental social. Assim, para que seja viável compreender o surgimento do direito social à moradia, é primordial tecer o percurso histórico das Constituições, bem como o dos direitos sociais. O primeiro texto constitucional pátrio é o de 1824. Com a independência, em 1822, e a consequente desvinculação com a Coroa Portuguesa, o país passou a exigir um novo documento para a nova nação que surgia, fazendo nascer, desse modo, àquela que ficou conhecida como a Constituição do Império.

A Constituição de 1824, embora seja marcada pelo individualismo, abriu as portas para uma visão mais social do direito. Como bem colocado pelos juristas Andrade et al. (2006) na obra História Constitucional do Brasil, "O constitucionalismo do Império, tanto o da Constituinte, estampada no Projeto de Antônio Carlos, como o da Carta de 1824, teve uma sensibilidade de precursora para o social, sem embargo de todo o teor individualista que caracteriza os dois documentos [...]". Todavia, a referida Constituição não fazia menção sobre quais seriam tais direitos sociais, apenas garantia que o Estado estaria a postos em caso de necessidade. Tal cenário perdurou durante as Cartas subsequentes.

Somente com a Constituição de 1934, após as instabilidades produzidas pelo Golpe de 1930, é que o direito social aparece de forma expressa no texto constitucional, com a introdução dos títulos relativos à ordem econômica e social, família, educação e cultura. Mesmo não fazendo referência ao direito à moradia, a Carta de 1934 "[...] quando disciplina o direito de propriedade, furta-se a garanti-lo 'em toda a plenitude', como fora da Constituição de 1891. Inova também de maneira substancial ao dispor que esse direito 'não poderá ser exercido contra o direito social ou coletivo'” (ANDRADE et al., 2006). Já é o primeiro indicio daquilo que hoje é conhecido como a função social da propriedade.

Prosseguindo, a Constituição Federal de 1937 seguiu o mesmo caminho, sem muitas novidades. Já em 1946, aquilo que vinha sendo consolidado como um Estado social democrático passa a sofrer abalos, ou, como dito por Andrade et al. (2006),

De 1946 a 1964, ano em que ocorre o colapso das estruturas constitucionais da terceira República com a outorga dos estatutos autoritários do movimento armado de 31 de março, as instituições se caracterizam por um tríplice aspecto: a Constituição é preponderantemente liberal, a ideologia é anti-individualista, a sociedade é ainda arcaica nas suas estruturas. O Estado social se faz instável. A Constituição entre em antagonismo com a sociedade [...] Nossa terceira República foi menos social que a ditadura da Revolução de 30, que a efêmera segunda República de 1934, que o próprio Estado Novo de Vargas. 
Substituindo a CF/46, em 1967 se fez nascer a Constituição do período ditatorial brasileiro. Mesmo com a Magna Carta de 1967 mantendo formalmente inalterável o seu texto social, as barbáries deixadas pela Ditadura Militar são incontáveis, mostrando total desrespeito ao principal instrumento jurídico do país, resultando em um grande retrocesso, responsável por minimizar os numerosos avanços obtidos no que diz respeito à justiça social.

No que concerne, especificamente, ao direito à moradia, a Constituição do governo militar também não se propôs a trabalhar o aludido direito, ainda que já houvesse previsão ao direito de habitação na Declaração Universal dos Direitos Humanos, documento datado de 1948. Esta declaração prevê, em seu artigo XXV, no 1, o seguinte rol de direitos sociais, nele constando o chamado direito à habitação:

\section{Artigo XXV}

1.Todo homem tem direito a um padrão de vida capaz de assegurar a si e à sua família, saúde e bem-estar, inclusive alimentação, vestuário, habitação, cuidados médicos e os serviços sociais indispensáveis, e direito à segurança em caso de desemprego, doença, invalidez, viuvez, velhice ou outros casos de perda dos meios de subsistência em circunstâncias fora de seu controle. (ONU, 2019)

Pode-se alegar que a Declaração Universal dos Direitos Humanos, por se tratar de uma recomendação da Organização das Nações Unidas, não obrigaria os países a adotarem o que nela está previsto, sendo este o motivo pelo qual a CF/67 ter deixado de incorporar o direito de habitação em seu texto. Ocorre que, de acordo com Comparato (2001),

Esse entendimento, porém, peca por excesso de formalismo. Reconhece-se hoje, em toda parte, que a vigência dos direitos humanos independe de sua declaração em constituições, leis e tratados internacionais, exatamente porque se está diante de exigências de respeito à dignidade humana, exercidas contra todos os poderes estabelecidos, oficiais ou não.

Portanto, mesmo sendo vista como uma mera recomendação, a Declaração Universal dos Direitos Humanos deveria ter sido devidamente observada pelo constituinte de 1967 e, caso isso tivesse acontecido, o direito social à moradia já estaria alçado seu lugar de destaque no país. Todavia, tal fato ainda demorou a vir à tona, como restará demonstrado a seguir.

Superado o governo militar, o país se depara com uma era absolutamente oposta, a fase da redemocratização, tendo como seu principal alicerce a Constituição Federal de 1988, apelidada de Constituição Cidadã. Pela primeira vez, os direitos sociais ganham um capítulo específico, de modo que o Capítulo II da CF/88 passa a tratar exclusivamente dos direitos sociais, estando estampado no seu artigo 6으 quais são esses direitos, vejamos:

Art. 60 São direitos sociais a educação, a saúde, a alimentação, o trabalho, a moradia, o transporte, o lazer, a segurança, a previdência social, a proteção à maternidade e à infância, a assistência aos desamparados, na forma desta Constituição. (BRASIL, 1988)

Registre-se que o direito à moradia não constava no texto constitucional original, ele foi inserido através de uma emenda constitucional, conforme elucidado por Gomes (2005) em sua dissertação para obtenção do título de mestre

Em 18 de junho de 1996, portanto quatro dias depois do termino da Conferência das Nações Unidas sobre Assentamentos Humanos (Habitat II), realizada em Istambul, Turquia, de 3 a 14 de junho de 1996, foi proposta no Senado a Emenda à CF/88 no29/1996, encabeçada pelo senador Mauro Miranda, com o objetivo de alterar a redação do art. 6 da CF/88 para 
incluir a moradia entre os direitos fundamentais sociais. A indicação do Brasil como relator da parte da Agenda do Habitat que tratava do direito à moradia, a participação ativa brasileira no evento, a difícil situação da moradia no Brasil e a ação dos movimentos sociais dos sem-teto, sem-terra e sem-emprego criaram o ambiente propício, na perspectiva internacional e interna, para que a moradia fosse inserida expressamente como direito fundamental social na $\mathrm{CF} / 88$.

Sem muitas dificuldades, haja vista as circunstâncias favoráveis, a proposta foi aprovada pelo Congresso Nacional, gerando a Emenda Constitucional no 26/2000, que possui esta redação:

Art. 1으 $\mathrm{O}$ art. 6을 da Constituição Federal passa a vigorar com a seguinte redação:

"Art. $6^{\circ}$ São direitos sociais a educação, a saúde, o trabalho, a moradia, o lazer, a segurança, a previdência social, a proteção à maternidade e à infância, a assistência aos desamparados, na forma desta Constituição." (NR)

Art. 2o Esta Emenda Constitucional entra em vigor na data de sua publicação.

Posto isto, tem-se o direito à moradia como um direito fundamental social, de maneira que, por fazer parte do rol de direitos sociais, o referido direito está inserido na lista de direitos da segunda geração, conforme disposto por Bonavides (2004), em sua obra Curso de Direito Constitucional:

São os direitos sociais, culturais e econômicos bem como os direitos coletivos ou de coletividade, introduzidos no constitucionalismo das distintas formas de Estado Social, depois que germinaram por obra da ideologia e da reflexão antiliberal do século XX. Nasceram abraçados ao princípio da igualdade, do qual não se podem separar, pois fazê-lo equivaleria a desmembrá-los da razão de ser que os ampara e estimula.

Após breve histórico das Constituições e o nascedouro do direito à moradia, será retratada, por meio de exemplos amplamente noticiados, a relação entre a prática de atos de esbulho/turbação com a não efetividade do direito à moradia, garantido constitucionalmente.

\section{A Relação de atos esbulhatórios e turbativos como reflexo da não efetividade do direito social à moradia}

Estando explicitados os conceitos básicos de esbulho e turbação, assim como a caminhada histórica do direito social à moradia no ordenamento jurídico, faz-se necessário determinar qual a ligação entre a prática dos atos de esbulho e turbação com a não efetividade do direito constitucional à moradia. Para que tal, recorrer-se-á a exemplos que estampam os noticiários brasileiros.

Antes de se passar a exposição de casos práticos de esbulho e turbação por conta da falta de moradia, é necessário compreender que o déficit por parte do ente estatal em oferecer moradias àqueles considerados hipossuficientes faz com que estes, por muitas vezes, busquem apoio em organizações conhecidas por suas lutas no que tange à moradia. O maior e mais conhecido movimento brasileiro nesta área é, sem dúvidas, o Movimento dos Trabalhadores Sem Teto - MTST, que tem como primeiro objetivo o direito à moradia digna.

Por meio de organizações como o MTST se verifica a resistência dos cidadãos hipossuficientes no enfrentamento de um sistema que se mostrou falho ao não proporcionar direito considerado básico para a existência digna de qualquer ser humano, de maneira que

Aqueles que não possuem uma habitação adequada buscam-na por meio de invasões a propriedades alheias com objetivo de pressionar os poderes públicos para que os terrenos invadidos sejam repassados para a construção de moradias para pessoas de baixa renda e atentá-los para a difícil situação em que vivem, ante a insuficiência de políticas públicas e as obrigações atribuídas ao Estado brasileiro para consolidar a proteção ao direito à moradia, como o dever de assegurar a dignidade da pessoa humana - por ser um Estado 
Democrático de Direito - e de executar as obrigações que lhe são devidas pelos tratados internacionais dos quais faz parte. (AMORIM, 2016)

Posto isto, passa-se a exposição de casos verídicos e emblemáticos de, principalmente, atos esbulhatórios, onde o principal objetivo dos agressores era a aquisição de uma moradia, tendo em vista que tal direito não foi devidamente efetivado pela máquina estatal. O primeiro grande exemplo é a ocupação do Edifício Prestes Maia, localizado na capital paulista, o qual vem sendo ocupado por centenas de famílias desde 2010, sob a orientação do Movimento Moradia na Luta por Justiça - MML, conforme o trecho abaixo colacionado de matéria jornalística:

Em pleno centro de São Paulo, um edifício abandonado de 21 andares abriga a maior ocupação da América Latina. É o Prestes Maia, uma antiga fábrica têxtil onde hoje vivem 478 famílias e que se transformou em um símbolo da luta por habitação.

Ocupado desde 2010, o prédio é uma gigante construção de cimento situada a poucos metros da Estação da Luz.

Durante anos, ostentou o título de segundo maior edifício ocupado da América Latina, mas escalou uma posição quando a 'Torre de David', em Caracas, um enorme arranha-céus de 45 andares invadido durante anos por famílias, foi desalojado pelo Governo venezuelano em 2015. (SANTANDREU, 2018)

Recentemente, outra ocupação eclodiu, desta vez em Pernambuco, especificamente na cidade de Recife, batizada de Marielle, em homenagem a vereadora carioca Marielle Franco, morta em 2018, a ocupação teve como objeto o Edifício SulAmérica, situado no centro da capital recifense. De acordo com revista Folha PE,

[...] O edifício SulAmerica, na praça da Independência, bairro de Santo Antônio, saiu da ociosidade de mais de dez anos e virou habitação para mais de $\mathbf{2 0 0}$ pessoas, sendo a maioria mulheres e crianças. Homenageando a vereadora carioca Marielle Franco, executada no último mês, as famílias que deram o nome dela à ocupação vêm ao poucos transformando o imóvel comercial em lar. Na rotina de convivência, há pessoas que perderam a condição de pagar um aluguel e estavam à beira da indigência e outras que moraram na rua por anos a fio e viram no prédio de seis andares a oportunidade de ter um teto pela primeira vez na vida. Em comum, o encantamento geral de estar num apartamento bem no centro da Capital.

Em Sergipe, o movimento de luta por moradia se tem a ocupação Beatriz Nascimento, localizada no Bairro Japãozinho, na cidade de Aracaju, cuja coordenação é dada pelo MTST. De acordo com informações colhidas no site do próprio MTST:

No último dia 7 de junho, o Movimento dos Trabalhadores Sem Teto obteve uma enorme e significativa vitória: a notícia da conquista da posse do terreno da Ocupação Beatriz Nascimento, no bairro do Japãozinho, Aracaju. Ao todo, cerca de 1.300 famílias vivem atualmente no local, que foi ocupado pelo MTST em novembro de 2017.

Pertencente ao poder público, descobriu-se que o terreno abandonado havia sido designado para receber uma escola há cerca de cinco anos. No entanto, o Governo de Sergipe garantiu que tanto a escola quanto as unidades de moradia popular vão ser construídas, coexistindo lado a lado. A unidade de educação deve atender toda a demanda local, segundo estudos feitos a pedido do governo. (MTST, 2018)

No âmbito cinematográfico, também, é possível encontrar exemplos da estreita relação entre atos de esbulho e turbação e a falta de efetividade do direito social à moradia. O filme Era o Hotel Cambridge (2016), dirigido por Eliane Caffé, retrata a situação de centenas de pessoas, dentre elas refugiados libaneses, palestinos, colombianos e congoleses, além de brasileiros, majoritariamente os nativos do nordeste do país, 
que lidam com a falta de moradia em pleno centro de São Paulo. A ocupação do Hotel Cambridge é organizada pela Frente de Luta por Moradia - FLM, que tem como líder Carmen Silva, responsável por pensar maneiras de evitar a reintegração de posse. Já determinada judicialmente.

Em crítica para $O$ Globo, relata o fato de que a referida obra envolve tanto realidade quanto ficção, de modo que aqueles que estrelam as cenas são atores profissionais e pessoas que realmente estão desabrigadas, como fica demonstrado no seguinte trecho:

O filme revela os detalhes dos conflitos em países do Oriente Médio que forçaram várias dessas pessoas a deixarem as suas casas. 'Eu vim porque tive que vir', diz um congolês. Algumas dessas conversas são reais, gravadas pela equipe de Eliane Caffé, que propositalmente buscou não atores para interagir com artistas profissionais - José Dumont e Suely Franco integram o elenco.

Estes foram alguns exemplos da intrínseca relação entre a falta de eficácia daquilo que está garantido constitucionalmente, o direito social à moradia, e a recorrente prática de esbulho e turbação sobre as propriedades privada e pública. Subsequentemente, buscar-se-á compreender como as ações possessórias podem ser utilizadas com o fito de se garantir a ordem da sociedade.

\section{Razões Ensejadoras para a Criação da Tutela Possessória}

Até o presente momento, pode-se dizer que restaram estabelecidos alguns pontos indispensáveis para a compreensão do problema do presente trabalho. Isto porque estão esclarecidas as teorias acerca da natureza da posse, a relação do homem com a posse ao longo da sua evolução histórica, bem como a forma pela qual tal relação se mostra fruto da legitimação da ordem social.

Por conseguinte, foram tratados os conceitos de esbulho e de turbação, juntamente com a ligação entre estes atos violentos e o direito social à moradia. Diante disso, faz-se preciso estabelecer a ligação entre o já explicitado e as razões pelas quais o ordenamento jurídico pátrio buscou criar as chamadas ações possessórias.

Antes de mais nada, é primordial citar quais as ações previstas na legislação brasileira, especificamente no Código de Processo Civil. As ações possessórias integram o Capítulo III, do terceiro Título, do CPC/2015, que está estampado na parte especial do referido códex. Estas ações estão dispostas entre os artigos 554 a 568 do referido diploma processual. Nas palavras de Bueno (2019), tem-se as espécies de ações possessórias:

As 'ações possessórias' são o procedimento especial de jurisdição contenciosa que tem como finalidade a proteção da posse. $\mathrm{Na}$ expressão estão compreendidas não só os pedidos de tutela jurisdicional voltados à manutenção (casos em que há turbação da posse, isto é, embaraços no exercício pleno da posse) e à reintegração (quando houver esbulho na posse, isto é, perda total ou parcial da posse) de posse, mas também o chamado interdito proibitório', voltado a proteção preventiva da posse, cabendo ao magistrado expedir 'mandado proibitório' com multa em detrimento de quem descumpri-lo. As duas primeiras hipóteses estão previstas no art. 560 e a terceira no art. 567, e dialogam suficientemente bem com a previsão do art. 1.210 do CC, segundo o qual: ' $O$ possuidor tem direito a ser mantido na posse em caso de turbação, restituído no de esbulho, e segurado de violência iminente, se tiver justo receio de ser molestado'.

Por meio deste breve fragmento, Bueno (2019) fornece algumas informações relevantes. A primeira delas é a de que existem três tipos de remédios possessórios, a saber, as ações de manutenção e de 
reintegração de posse, além do interdito proibitório, ação esta que não faz parte do objeto de estudo deste trabalho porque aqui está sendo debatido tão somente os atos violentos de turbação e esbulho, fazendo com que a prática da ameaça não seja discutida e, consequente, a ação de interdito proibitório. Noutro giro, o autor informa que as ações possessórias são responsáveis por tutelar tão somente o instituto da posse, como resta ainda mais evidente no seguinte trecho formulado pelo próprio Bueno (2019):

As 'ações possessórias' disciplinas pelos arts. 554 a 568 ocupam-se com a tutela da posse, e não da propriedade. Para a tutela jurisdicional desta não há, no CPC de 2015 - e já não havia no CPC de 1973 -, nenhum procedimento especial. É correto, até mesmo, sustentar, com fundamento no art. 557 de CPC de 2015 e no §2ㅇ do art. 1.210, que é vedado, durante as 'ações possessórias', que as partes demandem uma a outra questionando a propriedade.

Ratificando que o direito a ser protegido com as ações possessórias é o da posse e não o da propriedade, Montenegro Filho (2015) explica que

O proprietário do bem nem sempre é também o seu possuidor, para os fins da propositura da ação possessória, já que a posse é poder de fato, não sendo instituto que naturalmente deflui do domínio. Por presunção, o proprietário também é possuidor, não sendo a regra, contudo, de natureza absoluta. Na dinâmica forense, é extremamente comum verificarmos o ingresso da ação possessória pelo proprietário de imóvel, tentando recuperar posse que nunca exerceu sobre a coisa. 0 correto, nessa hipótese, seria o ajuizamento da ação de domínio, como tal a ação reivindicatória, jamais da ação possessória, que pressupõe o exercício de posse anteriormente à turbação ou ao esbulho.

Importante frisar que há doutrinadores que criticam a presença de três tipos diferentes de ações possessórias na lei processual brasileira, a exemplo de Neves (2019), que se mostra como ferrenho opositor da escolha do legislador pela divisão da tutela possessória em três espécies de ações:

Sempre me perguntei, à luz do CPC/1973, qual a serventia da existência de três diferentes ações possessórias no sistema. Tinha a esperança de que num eventual novo Código de Processo Civil esse anacronismo pudesse ser sanado, mas não foi desta vez, considerando que o novo diploma processual manteve expressamente as ações de reintegração de posse, manutenção de posse e interdito proibitório.

É claro que, no plano pratico, não se confundem as diferentes formas de agressão possessória, e não será a vontade legislativa que modificará esse panorama. Portanto, sempre haverá distinções entre esbulho, turbação e ameaça de agressão. Contudo, isso interesse tão somente ao direito material, não devendo ter qualquer relevância no plano processual.

Apesar da crítica, as três ações possessórias previstas no Código De processo Civil Brasileiro estão consolidadas, de modo que se passa a investigar sobre quais foram os motivos que levaram o legislador brasileiro a se debruçar sobre o direito à posse e sua proteção, isto é, quais as razões que ensejaram a criação da tutela possessória através das citadas ações. Segundo Marques (1923, citado por THEODORO JÚNIOR, 2016)

O fundamento filosófico da posse é, em resumo, o respeito à personalidade humana, aliado ao princípio social que não permite a ninguém fazer justiça por suas próprias mãos. Estando uma coisa sob a atuação material da pessoa, esta deve ser respeitada, como personalidade racional, de modo a não poder uma outra pessoa, fora da justiça, obrigar aquela a abrir mão da coisa possuída. Daí a proteção provisória ao fato da posse, sem cogitar preliminarmente do direito em que ela se estriba.

Assim, de acordo com esta primeira perspectiva, a posse é protegida tendo em vista o respeito a pessoa humana, visando, conjuntamente, a harmonia das relações sociais. Com isso, determinado cidadão não deve violar a posse do outro pelo fato de o possuidor ser seu semelhante, bem como pelo fato de existir 
um Estado-Juiz apto a dirimir quaisquer desavenças, de maneira que este pensamento remete ao direito natural à posse, discutido anteriormente. São, por essas razões, que o Estado toma para si a preocupação com a posse, fazendo com que, caso haja a ocorrência de atos violentos, os litigantes não procurem a solução de seus conflitos de maneira privada, mas, sim, que recorram ao Poder Judiciário.

Em complemento ao acima exposto, nas palavras de Theodoro (2016), “[...] a posse é protegida pela lei porque assim o exige a paz social, que não subsiste num ambiente onde as situações fáticas estabelecidas possam ser alteradas por iniciativa de particulares, por meio da justiça das próprias mãos". Em contrapartida, outros autores, vislumbram a proteção possessória como um efeito decorrente do direito à posse, podendo esta proteção ser realizada, inclusive, pelo próprio possuidor, por meio da intitulada autotutela. Nesta esteira, Gonçalves (2017) afirmando que

A proteção conferida ao possuidor é o principal efeito da posse. Dá-se de dois modos: pela legítima defesa e pelo desforço imediato (autotutela, autodefesa ou defesa direta), em que o possuidor pode manter ou restabelecer a situação de fato pelos seus próprios recursos; e pelas ações possessórias, criadas especificamente para a defesa da posse (heterotutela).

Observa-se, desse modo, que a existência da autotutela como uma alternativa para defesa da posse contraria o que foi dito anteriormente por Marques (1923) e por Theodoro (2016), já que ambos os autores se filiam ao entendimento de que a tutela possessória fora criada justamente para que a resolução dos conflitos fosse dada por um instrumento público, por meio do direito de ação, e não mediante a utilização de forças próprias, amenizando, assim, o advento de demais conflagrações. Não se pode negar que o sistema jurídico brasileiro prevê a autodefesa da posse, estando prevista no artigo. 1.210, § 1으, do CC:

Art. 1.210. O possuidor tem direito a ser mantido na posse em caso de turbação, restituído no de esbulho, e segurado de violência iminente, se tiver justo receio de ser molestado.

$\S 1$ 으 possuidor turbado, ou esbulhado, poderá manter-se ou restituir-se por sua própria força, contanto que o faça logo; os atos de defesa, ou de desforço, não podem ir além do indispensável à manutenção ou restituição da posse. (BRASIL, 2002)

Ainda que possa parecer discrepante a existência, no mesmo sistema jurídico, de instrumentos de autotutela, por meio de recursos próprios, e de heterotutela, mediante a ferramenta processual, não se pode negar que ambos possuem o mesmo objetivo: proteger o possuidor de eventuais abusos na sua posse. E, como consequência, manter o equilíbrio das relações sociais, diminuindo ou solucionando eventuais embates sobre à posse.

Assim, é plausível a constatação de que o legislador pátrio se preocupou em salvaguardar a posse, possibilitando a defesa do bem objeto de posse por meio das ações possessórias, subdividas em três, uma para cada tipo de agressão. Além disto, os tutelados também, caso não queiram se socorrer da autoridade judiciária, possuem amparo legal para manter ou recuperar suas posses por meio de suas próprias mãos, já que existe o mecanismo da autotutela.

Em todo o caso, as ações possessórias existem e foram pensadas como mecanismo de amparo ao possuidor em caso de uma possível ocorrência de esbulho, turbação ou ameaça, fenômenos já explicados em capítulo anterior, servindo de antídoto para os conflitos possessórios e consequente retomada da ordem social. 


\section{CONCLUSÕES}

Perante todo o exposto ao longo deste trabalho, chega-se ao momento no qual algumas pontuações devem ser feitas. Discutir posse e propriedade na sociedade brasileira atual vai muito além da seara jurídica, haja vista se estar diante de um gigantesco mercado de consumo, onde ter ou deter é sinônimo de poder. Aqueles que são donos ou possuidores de algo são vistos como poderosos, enquanto que os menos abastados exercem o papel de singelos figurantes neste cenário. Desta forma, o presente estudo contribui para o entendimento de uma relação que, além de jurídica, também é humana, já que compreender como o homem interage com aquilo que possui implica na assimilação da forma como os indivíduos se comportam e se relacionam entre si.

Por muitas vezes houve uma recapitulação histórica, sendo, com isso, possível a assimilação de vários conceitos aqui discutidos, como por exemplo o vínculo do homem com o instituto possessório e os modos pelos quais tanto a posse como a propriedade vêm contribuindo para a legitimação da ordem social. Além disso, o exame de atos atentatórios a posse, como o esbulho e a turbação, mostrou-se imprescindível para a percepção de que tais posturas violentas guardam estreita relação com a manutenção ou perda da ordem social.

Outra questão de manifesta relevância aqui aventada diz respeito ao fato de o direito social à moradia ser um dos motivos que levam a prática de atos esbulhatórios e turbativos, uma vez que a ausência do cumprimento efetivo deste direito gera uma verdadeira desordem social a partir do momento que pessoas se veem obrigadas a violentarem a posse alheia visando a conquista de um lar digno, prova disso são os inúmeros exemplos colacionados durante todo o trabalho.

Após tantos pontos de discussão, não restam dúvidas de que o cerne da questão é procurar entender de que forma as ações possessórias dispostas no Código de Processo Civil constituiriam uma ferramenta de manutenção, ou até reestabelecimento, da ordem da sociedade. Pode-se dizer que tal objetivo fora alcançado, já que restaram esclarecidas quais as espécies de ações possessórias estão previstas no Códex processualista, além da função de cada uma delas, bem como a forma como tais remédios garantem a paz da sociedade brasileira, ao menos no que tange ao aspecto possessório.

Incertezas quanto à utilidade prática deste estudo poderão ser levantadas, todavia, é correto pontuar que há sim um aproveitamento tanto para o mundo acadêmico quanto para o universo da prática forense. Ora, se para que haja uma tutela jurisdicional qualificada, faz-se necessário a presença de operadores do direito qualificados, é primordial que estes operadores sejam dotados de uma adequada carga teórica, de maneira que o presente estudo permite a concepção do tema como um todo, desde as suas origens até a problemática enfrentada atualmente, facilitando, assim, as resoluções dos conflitos que diariamente adentram o Poder Judiciário.

Com isso, conclui-se que o assunto aqui abordado chamará a atenção para questões sociais essenciais, principalmente no que diz respeito a falta de efetividade de um direito constitucionalmente garantido, o direito social à moradia, pois, como ficou demonstrado, é a falta de moradia digna que, por 
muitas vezes, leva ao cometimento de atos violentos contra a posse, causando enormes conturbações sociais. Espera-se, portanto, que está temática não seja colocada de lado e que haja uma maior preocupação por parte daqueles que detém os instrumentos responsáveis por uma efetiva mudança de paradigma, através de políticas públicas, para que com isso a ação judicial não seja a única fonte de cura para tantas mazelas.

\section{REFERÊNCIAS}

AMORIM, E. G. O. C.. O conflito entre posse e propriedade nos casos de ocupação de imóveis particulares. Cadernos de Iniciação Cientifica, São Paulo, v.13, 2016.

ANDRADE, P.; BONAVIDES, P.. História constitucional do Brasil. 8 ed. Brasília: OAB, 2006.

MTST. Movimento dos Trabalhadores Sem Teto. Sergipe conquista terreno para a ocupação Beatriz Nascimento. Aracaju: MTST, 2018.

BONAVIDES, P.. Curso de direito constitucional. 14 ed. São Paulo: Malheiros, 2004.

BRASIL. Constituição da República Federativa do Brasil de 1988. Brasília: Presidência da República, 2016.

BRASIL. Lei n. 10.406, de 10 de janeiro de 2002. Institui o Código Civil. Brasília: Presidência da República, 2002.

BRASIL. Lei n. 13.105, de 16 de março de 2015. Institui o Código de Processo Civil. Brasília: Presidência da República, 2015.

BUENO, C. S.. Manual de direito processual civil: volume único. 5 ed. São Paulo: Saraiva Educação, 2019.

CÂMARA, A. F.. Lições de direito processual civil. 16 ed. Rio de Janeiro: Lumen Juris, 2010

COMPARATO, F. K.. A afirmação histórica dos direitos humanos. 2 ed. São Paulo: Saraiva, 2001.

DINIZ, M. H.. Curso de direito civil brasileiro: direito das coisas. 18 ed. São Paulo: Saraiva, 2002.

MONTENEGRO FILHO, M.. Curso de direito processual civil: medidas de urgência, tutela antecipada e ação cautelar, procedimentos especiais. 11 ed. São Paulo: Atlas, 2015.

GIANULO, W.. Procedimentos especiais: doutrina, prática forense e legislação. São Paulo: Jurídica Brasileira, 2008.
GOMES, F. D.. Direito Fundamental Social à Moradia: legislação internacional, estrutura constitucional e plano infraconstitucional. 2005. Dissertação (Mestrado) Universidade Federal do Rio Grande do Sul, Porto Alegre, 2005.

GONÇALVES, C. R.. Direito civil brasileiro: direito das coisas. 12 ed. São Paulo: Saraiva, 2017.

HOBBES, T.. Leviatã: ou matéria, forma e poder de um estado eclesiástico e civil. São Paulo: Martins Fontes, 2003.

THEODORO JÚNIOR, H.. Curso de direito processual civil: procedimentos especiais. 50 ed. Rio de Janeiro: Forense, 2016.

LOCKE, J.. Segundo tratado sobre o governo. Coleção Os Pensadores. 2 ed. São Paulo: Abril Cultural, 1978.

NEVES, D. A. A.. Manual de direito processual civil: volume único. 11 ed. Salvador: JusPodium, 2019.

ONU. Organização das Nações Unidas. Declaração Universal dos Direitos Humanos. Aprovada pela Resolução 217 A (III) da Assembleia Geral das Nações Unidas em 10 de dezembro de 1948. Nova lorque: ONU, 2019.

ROSSEAU, J.-J.. O contrato social: princípios do direito político. 4 ed. São Paulo: Martins Fontes, 2006.

SANTANDREU, A.. Edifício Prestes Maia, o maior símbolo das ocupações na América Latina. São Paulo: Agencia EFE, 2018.

TARTUCE, F.. Manual de direito civil: volume único. 7 ed. Rio de Janeiro: Forense, 2017.

VENOSA, S. S.. Direito civil: direitos reais. 3 ed. São Paulo: Atlas, 2003.

A CBPC - Companhia Brasileira de Produção Científica (CNPJ: 11.221.422/0001-03) detém os direitos materiais desta publicação. Os direitos referem-se à publicação do trabalho em qualquer parte do mundo, incluindo os direitos às renovações, expansões e disseminações da contribuição, bem como outros direitos subsidiários. Todos os trabalhos publicados eletronicamente poderão posteriormente ser publicados em coletâneas impressas sob coordenação da Cognitionis Publishing, da Companhia Brasileira de Produção Científica e seus parceiros autorizados. Os (as) autores (as) preservam os direitos autorais, mas não têm permissão para a publicação da contribuição em outro meio, impresso ou digital, em português ou em tradução. 